\title{
Ownership Concentration and Bank Performance: Evidence from MENA Banks
}

\author{
Rim Boussaada $^{1}$ \& Majdi Karmani ${ }^{2}$ \\ ${ }^{1}$ University of Tunis, High Institute of Management, GEF-2A Lab, Tunis, Tunisia \\ ${ }^{2}$ La Rochelle Business School, Irgo, France \\ Correspondence: Rim Boussaada, University of Tunis, High Institute of Management, GEF-2A Lab, Tunis, \\ Tunisia. E-mail: boussaada.r@gmail.com
}

Received: December 11, 2014

Accepted: December 29, 2014

Online Published: February 27, 2015

doi:10.5539/ijbm.v10n3p189

URL: http://dx.doi.org/10.5539/ijbm.v10n3p189

\begin{abstract}
This paper analyzes the impact of ownership concentration on MENA banks' performance over the period 2004-2011. The sample includes 38 commercial banks belonging to ten countries of the MENA region. We use an econometric method that deals with the endogeneity problems that have arisen in the corporate governance literature. We show that ownership concentration is significant in explaining performance differences between MENA banks. Our analysis shows that bank performance depends on the identity of large shareholder. Banks tend to exhibit higher levels of performance if their largest shareholder is foreign. However, we find a negative relationship between state ownership and bank performance.
\end{abstract}

Keywords: banks, ownership concentration, performance, MENA

\section{Introduction}

The collapse of the global financial system has exacerbated the debate about the vulnerability of a banking system considered until this crisis as powerful, dynamic and innovative. These changes have raised the problem of the soundness of the banking system at the forefront of researchers, academics and politicians. Indeed, banks play a dominant role in financial systems and they represent economic growth engines (King \& Levine, 1993; Levine, 1997). Recently, the Basel committee on Banking supervision (2014) revised principles of corporate governance within banks built on the Committee's 2010 document "Principles for enhancing corporate governance". The committee has highlighted, again, that the effective corporate governance is critical to the proper functioning of a bank, the banking sector and the economy.

For the Basel committee, internal control is a major element in the bank governance (Maati \& Maati-Sauvez, 2012). In this line, we notice several studies lending a special focus to the relationship between ownership structure and bank performance (La Porta et al., 2002; Hasan \& Marton, 2003; Berger et al., 2005; Bonin et al., 2005). In fact, differences in identity, concentration and resource among owners settle their relative power, incentives and ability to monitor managers (Douma et al., 2006). In recent years, authors have started to pay attention to the banking sectors in emerging countries (Bonin et al., 2005; Weill, 2007) (Note 1). However, we notice the lack of research focusing on bank performance in developing countries, especially in the Middle East and North Africa (MENA).

The MENA region is worth studying for several reasons. Firstly, the financial systems of the MENA countries remain excessively bank based despite the reforms undertaken to establish a market-based financial sector and promote financial development. Indeed, the financial system in this region is dominated by banks (Creane et al., 2004). Secondly, State banks still dominate in most MENA countries (Farazi et al., 2013), foreign ownership is on the rise and the ownership structure is highly concentrated (Rochat et al., 2011). Thirdly, the ownership structure has greater importance in developing countries where protection of shareholders' rights is weak and this is the case of the MENA countries (Ayadi et al., 2011).

There are some country-level studies (Isik et al., 2004 for Jordan; Omran, 2007 for Egypt and Turk-Ariss, 2008 for Lebanon; Bennaceur \& Goaied, 2008 for Tunisia; Isik \& Hassan, 2003; Bektas \& Keymak, 2009 for Turkey) that investigate the overall performance of these banking sectors. To best of our knowledge, only Kobeissiand Sun (2010) and Farazi et al. (2013) study the impact of ownership structure on bank performance in the MENA 
region. Our study is similar to the latters in some methodological aspects, but also bears a few major differences.It should be noted that empirical findings may be altered by the endogeneity problem which is among the main econometric problems that have arisen in the corporate governance literature. Specifically, our research is different from the previous ones; in so much as it attempts to explore the impact of the ownership structure on the bank performance in the MENA context by using an econometric method that deals with the endogeneity problems.

The contribution of this study is twofold: First, it aims to fill the gap in banking literature by focusing on the banking sector in the MENA region. Second, it aims to gain an understanding of a significant determinant, ownership structure, which is associated with bank performance by studying the ownership concentration of 38 banks in 10 MENA countries. Indeed, the research on the influence of ownership concentration on corporate performance is scarce for financial firms (Azofra \& Santamaria, 2011).

Our research paper analyses the impact of ownership concentration on the performance of MENA banks over the period 2004-2011. We explore this relationship by using generalized method of moments (GMM) system approaches. Our results support the idea, commonly accepted, that bank ownership structure is a determinant factor for bank performance. More specifically, the results show that ownership concentration affects the performance of the MENA banks. Particularly, the ownership concentration has a significant and positive effect on bank performance, while the control by the State is associated with a bad performance. Another important finding is that the foreign-owned banks tend to be more profitable than domestic banks.

The remainder of this paper is structured as follows. In the second section, we review the literature on the topic and present our hypotheses. In the third section, we present our methodological approach and provide the results of our empirical analysis in the fourth section. Then, we conclude.

\section{Related Literature}

In our study we will focus on the degree of ownership concentration and the large shareholder's identities to evaluate the bank performance.

\subsection{Ownership Concentration}

The extant literature addresses the issue of ownership structure and performance in the banking sector from the theory of the firm perspective and the separation of ownership and control (Berle \& Means, 1932; Jensen \& Meckling, 1976). Two main hypotheses appear to compete with regard to the link between ownership concentration and performance: convergence of interest hypothesis and entrenchment hypothesis.

The agency problems in banks are larger and more complex than those observable for the non-financial firms. The bank's managers have fiduciary responsibilities to the shareholders, depositors and regulator. The agency costs associated with control concentration may be greater in the banking sector because of its unique features. According to Jensen and Meckling (1976), the more the ownership structure is dispersed, the more the agency costs are higher. The presence of large shareholders mitigate the classic owner-manager agency problems through their strong incentives to collect information and substantial power to influence management (Shleifer \& Vishny, 1986), which would result in a more efficient governance structure leading to an important value for shareholders. For the agency theory, the large shareholders have incentives to manage the bank effectively. A large shareholder can reduce discretionary management behavior and increase corporate value. In the banking sector, large shareholders have strong incentives to monitor bank management through tight oversight of lending practices, operational efficiency, and risk management (Unite \& Sullivan, 2003).

However, the ownership concentration stresses the entrenchment of the large shareholder and the incentives to expropriate minority shareholders and depositors. Large shareholder can obtain private benefits of control which will negatively affect the corporate value (Johnson et al., 2000; Gutiérrez \& Tribo, 2004). In the banking sector, the extraction of private benefits is detrimental not only to minority shareholders but also to the depositors. With large power, dominant shareholder may expropriate small ones (Stulz, 1988). It induces insider expropriation, distorts management decision making and may reduce small-shareholder welfare (Shleifer \& Vishny, 1997).

Large shareholder may collude with managers to expropriate depositors, by taking on excessive risk. Indeed, controlled banks are often the capital supplier of their large shareholders (Williams \& Nguyen, 2005). This situation may deteriorate performance and increase in non-performing loans (Boyd et al., 1998). Depositors and small shareholders have neither the information nor the incentives to monitor the managers. The monitoring activity is very difficult in the banking sector because it is characterized by opacity (Morgan, 2002). Consequently, the expropriation of benefices by insiders is easier. In summary, the effects of ownership concentration on bank performance depend on the interplay between the incentives of large shareholders to 
enhance performance, improve cost efficiency, and exercise prudent risk management and their desire to expropriate.

Previous studies on the relationship between ownership concentration and bank performance produced varied findings. Some of empirical researches have shown a positive association between ownership structure and bank performance (Caprio et al., 2007; Azofra \& Santamaria, 2011). The author's results prove that ownership concentration is an effective lever of governing banks since larger ownership concentration can reduce the agency problem between owners and managers. The same researches suggest that ownership concentration reduce the costs of management monitoring and generate a better performance. However, other studies have reported that there is a negative association between ownership concentration and bank performance (Lin \& Zhang, 2009). In the same vein, some researchers have shown that there is no relationship between ownership concentration and performance (Iannotta et al., 2007).

Regarding the MENA region, recently, Al-Amarneh (2014) investigates the performance of Jordan banks over the period 2000-2012 and shows that ownership concentration positively affects the performance while foreign ownership has a positive and significant effect on bank performance.

In our study, we expect a positive association between ownership concentration and bank performance:

H1: There is a positive relationship between ownership concentration and bank performance.

\subsection{State Ownership}

According to the social welfare theory (Atkinson \& Stiglitz, 1980), public banks may pursue social and economic development objectives which render them less profitable and more risky compared to private banks. Public banks are viewed as a mechanism to maximize social welfare (Banerjee, 1997). Banks controlled by State must adopt a more active strategy when the frequency of market failures is high in certain sectors; they may focus on those linked with external funding, information asymmetries, intangible assets and substantial spillovers (Levy Yayeti et al., 2007).State owned banks are less profitable because they maximize broader social objectives.

However, according to the political theory (Shleifer \& Vishny, 1994), the banks controlled by the State are inefficient and politically used (Omran, 2007). Hu et al. (2004) indicate that an increase in the state's shareholding facilitates political lobbying. Indeed, the state owned banks are more vulnerable to political lobbying than private banks. They are subject to less monitoring (Megginson, 2005). According to this view, politicians create and maintain state-owned banks not to channel funds to economically efficient uses, but rather to maximize politicians' personal objectives (Sapienza, 2004).

Several American empirical studies show that state owned banks are generally less efficient (Maati \& Sauvez-Maati, 2012). Based on a sample of 18 Argentine banks over the period 1993-1999, Berger et al. (2005) find that state-owned banks tend to have poorer long-term performance on average than domestically-owned banks or foreign-owned banks. Micco et al. (2007) show that state-owned banks located in developing countries tends to have returns on assets that are much lower than comparable domestic privately-owned banks.

In Egypt, Mohieldin and Nasr (2007) show several areas of deficiencies in public sector banks, including a relatively low capital adequacy ratio, poor quality of banks' assets, high ratio of nonperforming loans, modest earnings and profitability, declining liquidity, and a fair level of exposure to several forms of financial markets risk. Kobeissi and Sun (2010) study the relation between ownership structure and bank performance. The authors conclude that, in 17 MENA countries, private banks perform better than state banks. Finally, Farazi et al. (2013) investigates the trends in the structures of MENA banking systems. They found that the performance of state banks is poorest than private banks during the period 2001-2008.

Hence, we formulate the following hypothesis:

H2: There is a negative relationship between state ownership and bank performance.

\subsection{Foreign Ownership}

Foreign participation in a bank's capital appears to be a signal of "good governance" (Gulamhussen \& Guerriero, 2009). It is frequently asserted that foreign bank entry can render national banking markets more competitive and thereby can force domestic banks to start operating more efficiently (Berget et al., 2000; Claessens et al., 2001; Beck et al., 2005). In this vein, Berger et al. (2000) develop two main hypotheses: the home field advantage hypothesis versus the global advantage hypothesis. Under the home field advantage hypothesis, domestic institutions are generally more efficient than foreign institutions. The banks controlled by foreigner may suffer from difference in language, culture and regulatory and supervisory structures. In this context, the domestic owned banks have some comparative advantage that foreign owned banks lack. Under the global advantage 
hypothesis, foreign institutions can overcome cultural and institutional barriers and operate more efficiently than domestic ones. The foreign owners may influence the bank management to adapt a more transparent, competitive and efficient operating strategy (Choi \& Hasan, 2005). The theoretical debate about the impact of foreign ownership on the bank's performance is still unresolved. Empirical evidence show that foreign owned banks have superior performance than to domestic owned banks just in developed countries (Demirgüç-Kent et Huizinga, 2000; Claessens et al., 2001; Lensink et Hermes 2004; Bonin et al., 2005) and not in developing countries (De Young et Nolle, 1996; Vander, 1996; Berger et al., 2000; Micco et al., 2007).

In MENA region, Kobeissi and Sun (2010) argue that the presence of foreign banks have a positive impact on the performance of domestic banks. Their results showed that private banks, especially the majority foreign-owned private banks, were significantly better performers. In this vein, we would like to test the global advantage hypothesis (Berger et al., 2000) in the MENA banking sector. Accordingly, we want to test the following hypothesis:

H3: There is a positive relationship between foreign ownership and bank performance.

\section{Empirical Study}

\subsection{The Sample}

The purpose of this paper is to explore the impact of the ownership structure on the MENA bank performance. The sample includes 38 commercial banks belonging to 10 countries (Note 2) of the MENA region for the years 2004-2011. The choice of the period of the analysis is primarily motivated by the availability and continuity of bank's information. Moreover, MENA banking systems show resilience during the subprime crisis and banks withstood the effects of the crisis relatively well (Rochat et al., 2011) (Note 3). Thus, we don't exclude the period following the year 2007 as the data are not contaminated by the financial turmoil. Financial data and ownership information are collected from The Bureau Van Dijk's Bankscope database. Besides, we use the World Governance Indicators produced by Kaufmann et al. (2010) to control for the quality of institutions (Note 4). These data cover 215 economies over the period 1996-2011, for six dimensions of governance. Finally, to capture macroeconomics differences between countries, we refer to the World Bank Data.

\subsection{Variables Used}

We use the ROA (return on assets) and ROE (return on equity) as indicator of bank performance. These measures are the most common use of performance variables (Demirgüç-Kunt and Huizinga, 2000; Claessens et al., 2001; Mahajan et al., 2012). Regarding the ownership concentration, will use two main measures of ownership structure: the degree of ownership concentration and the large shareholder's identities to evaluate the bank performance. As the study of Shehzad et al. (2010) we employ three indicators of ownership concentration. $O C 1$ is a dummy variable that is one in case there is at least one owner with shareholdings greater than $10 \%$ and zero otherwise. $O C 2$ is a dummy variable that is one in case there is at least one owner with shareholdings greater than $25 \%$ and zero otherwise. $O C 3$ is a dummy variable that is one in case there is at least one owner with shareholdings greater than $50 \%$ and zero otherwise. As the study of Al-Amarnah (2014), we employ two indicators of ownership structure. State is a dummy variable that is one if the bank is the majority state-owned and zero otherwise. Foreign is a dummy variable that is one if the bank is majority foreign-owned and zero otherwise.

We add others variables to control for bank size (Size), Charter value (Charter) and bank capital (Capital). We use the NPLs ratio as a proxy for bank quality asset. We want to capture the extent to which banks' loan portfolios are being affected by non-performing loans and having an impact on performance. We also adjusted for country specific variables by controlling for economic and institutional environment. To control for economic expansion we use the GDP Growth (GDP_gr). To account for the differences in the institutional quality amongst countries, we include the Institutional quality (IQ) which is the Regulatory Quality indicator produced by Kaufmann et al. (2010). Besides, we include year dummies to capture year effect. Table 1 shows the data source and a brief description of our key variables used in this study. 
Table 1 . Summary of the variables

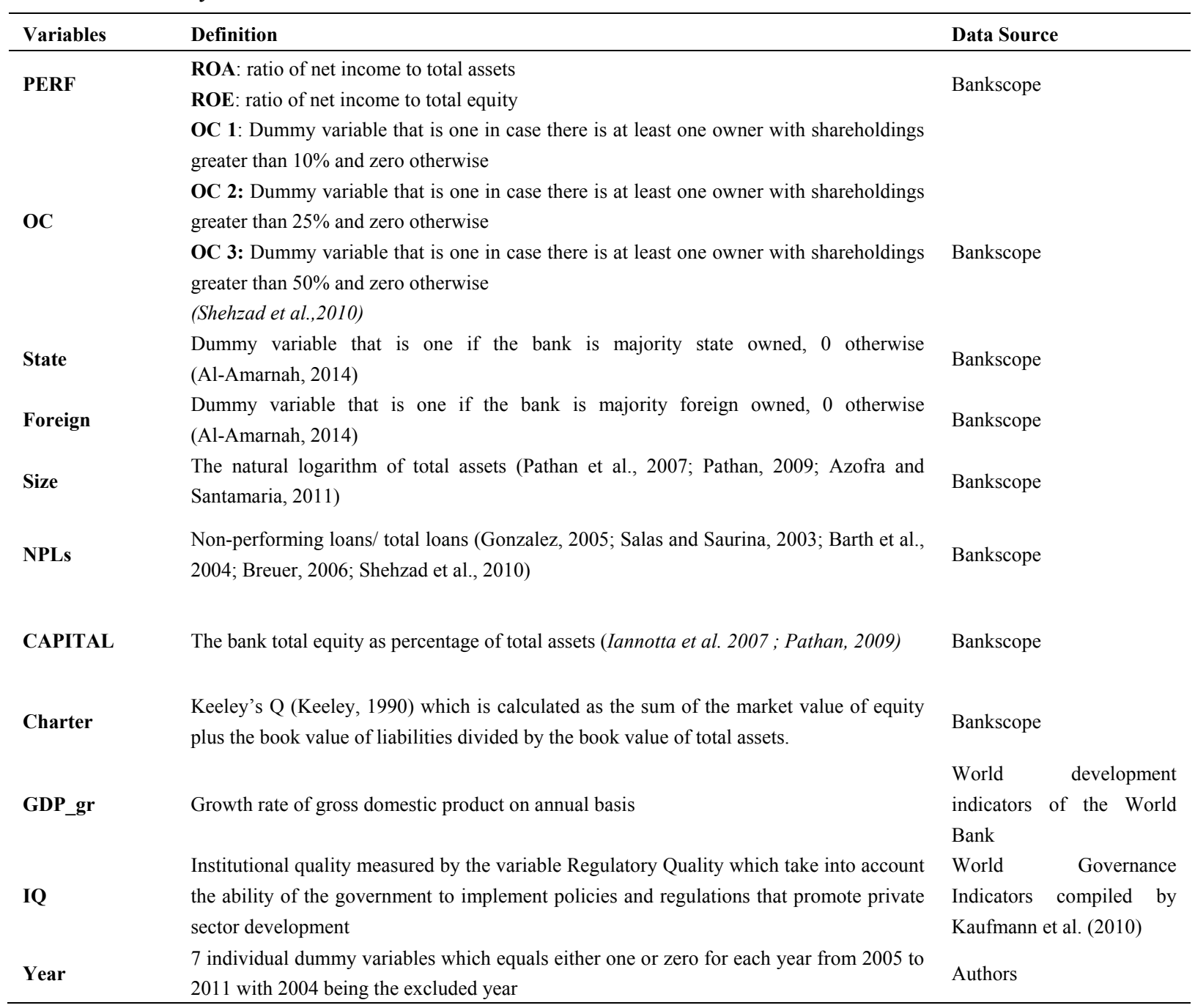

\subsection{Methodology}

We use the following regression model to examine the impact of the ownership concentration on the performance of MENA banks.

$$
\text { Performance }_{i, t}=f\left(\text { ownership concentration }_{i, t} \text {, control } \text { variables }_{i, t}\right)+\varepsilon t_{i, t}
$$

In which the subindexi identifies the bank and the subindex $t$ indicates the period. In our study, we opt to estimate a dynamic panel data model. Indeed, the ownership concentration and board structure are endogenously formed (Andres \& Vallelado, 2008; Pathan, 2009). To address the endogeneity problem, we use the System Generalized Method of Moments (SGMM) estimators developed by Arellano and Bover (1995) and Blundell and Bond (1998). The SGMM simultaneously takes into account the unobserved heterogeneity, the endogeneity and the heteroskedasticity of the explanatory variables for panel data (Andres \& Vallelado, 2008). Also, the SGMM allows us to solve the problem of simultaneity between the ownership structure and corporate value (Demsetz \& Villalonga, 2001). Like Azofra and Santamria (2011) and since our sample size is not very large, we use the procedure suggested by Windmeijer (2005) that improves the robustness of our results. The lagged levels of explanatory variables are used as instruments. To test model specifications validity, we use the Sargan test of over-identifying restrictions that checks the validity of the instruments. We also include the AR (1) and AR (2) to test the first and second-order serial correlation, respectively. 


\section{Empirical Results}

\subsection{Descriptive Statistics}

Table 2. Descriptive statistics

\begin{tabular}{|c|c|c|c|c|}
\hline \multicolumn{5}{|c|}{ Continuous variables } \\
\hline Variables & Mean & Min & Max & SD \\
\hline ROA & 0.10 & -0.10 & 3.49 & 0.44 \\
\hline ROE & 0.13 & -1.11 & 0.79 & 0.13 \\
\hline Size & 15.88 & 11.58 & 19.65 & 1.79 \\
\hline NPLs & 10.70 & 0.21 & 47.89 & 9.63 \\
\hline Capital & 0.11 & 0.03 & 0.25 & 0.04 \\
\hline Charter & 0.92 & 0.74 & 1.26 & 0.08 \\
\hline Gdp_gr & 0.05 & -0.01 & 0.20 & 0.04 \\
\hline IQ & 0.10 & -0.49 & 0.83 & 0.32 \\
\hline \multicolumn{5}{|c|}{ Dummy variables } \\
\hline & \multicolumn{3}{|c|}{ Modality } & Frequency \\
\hline \multirow{2}{*}{$\mathrm{OC} 1$} & \multicolumn{3}{|c|}{ 1: at least one owner with shareholdings greater than $10 \%$} & $65.78 \%$ \\
\hline & \multicolumn{3}{|c|}{0 : otherwise } & $34.21 \%$ \\
\hline \multirow{2}{*}{$\mathrm{OC} 2$} & \multicolumn{3}{|c|}{ 1: at least one owner with shareholdings greater than $25 \%$} & $48.68 \%$ \\
\hline & \multicolumn{3}{|c|}{0 : otherwise } & $51.31 \%$ \\
\hline \multirow{2}{*}{$\mathrm{OC} 3$} & \multicolumn{3}{|c|}{ 1: at least one owner with shareholdings greater than $50 \%$} & $35.19 \%$ \\
\hline & \multicolumn{3}{|c|}{0 : otherwise } & $64.80 \%$ \\
\hline \multirow{2}{*}{ State } & \multicolumn{3}{|c|}{ 1: The large shareholder is the state } & $13.15 \%$ \\
\hline & \multicolumn{3}{|c|}{0 : otherwise } & $86.84 \%$ \\
\hline \multirow[t]{2}{*}{ Foreign } & \multicolumn{3}{|c|}{ 1: The large shareholder is foreign } & $50.32 \%$ \\
\hline & \multicolumn{3}{|c|}{0 : otherwise } & $49.67 \%$ \\
\hline
\end{tabular}

According to the descriptive statistics provided in Table 2, we notice that MENA banks are characterized by a high level of ownership concentration with $65.78 \%$ of bank shareholders holding a share of capital that is greater than $10 \%, 48.68 \%$ of them having more than $25 \%$ of the shares and approximately $35 \%$ having control blocks exceeding $50 \%$ of the shares. The State and the foreigners hold on average $14 \%$ and $50 \%$ of the bank's capital respectively. Also, we notice that the average ROA and ROE is about 0.10 and 0.13 .

The Pearson's pair-wise correlation matrix (see the appendix) and the average variance inflation factor (AVIF) of 1.70 and the maximum VIF (Note 5) of 2.10 indicate the inexistence of any multicollinearity problems. The correlation coefficient between the variables doesn't exceed the limit at which we assume the presence of a serious problem of multicollinearity, ie 0.8 (Kennedy, 2003).

\subsection{Regression Results}

Table 3 presents the results from the regressions of ownership structure variables and control variables on our performance measure. According to the table, the models seem well-fitted with statistically significant test statistics for second-order autocorrelation in the first difference (AR1), and statistically insignificant test statistics in the second difference (AR2). Likewise, we confirm the validity of the instruments using the Sargan over-identification test. In all models, the statistically insignificant Sargan test indicates that instruments are valid in the estimations (Note 6).

On the whole, we find that the ownership concentration have a significant effect on the performance of the MENA banks. The coefficients estimates indicate that the ownership concentration for a threshold of $10 \%(O C 1)$ $25 \%(O C 2)$ and $50 \%(O C 3)$ are positive and significant. These suggest that whatever the threshold of ownership concentration, the large shareholder increases the bank performance measured by ROA and ROE. Concentrated ownership provides more effective monitoring, which should lead to better performance in MENA banks. Overall, the results in Table 3 imply that, for banks with controlling owners, the convergence of interest effect acts as the predominant force shaping bank operations. This result is consistent with Laeven and Levine (2009) and Haw et al. (2010) who find that banks with higher ownership concentration are associated with higher performance. 
Our results show that bank performance depends on the identity of large shareholder. Consistent with the expectations, Model 3 and Model 4 in table 4 show that the control by the foreigners is significantly and positively associated with ROA and ROE which suggests that domestic owned banks exhibit poorer operating and market performance. We confirm the globe advantage hypothesis of Berger et al. (2000) who explain that foreign banks benefit from competitive advantages relative to domestic banks,

This finding has been previously documented for developing countries as well (Demirgüç-Kuntand Huizinga, 2000; Micco et al., 2004; Kobeissi \& Sun, 2010). In other words, foreign banks are more profitable than private domestic banks in MENA region. It seems that their presence in the MENA banks involves a better quality of management. Foreign owners might transfer or require top management adopt certain operational and management strategies in order to maximize their returns on investment. This, in turn, results in higher MENA bank performance. Indeed, foreign-owned banks tend to rely on head office risk functions and approaches (Rochat et al., 2011). It can be said that foreign properties contribute to the amelioration of MENA banks profitability.

The coefficient for State is negative and significant in the two regressions (Model 3 and 4), indicating that state owned banks control tends to have poorer performance. The result suggests that state ownership is less efficient than private ownership and it is consistent with our hypothesis. The lower performance may arise from the less efficient management associated with the concentration of control rights in hands of the state. It could also indicate that state banks are plagued by the financing of social and political projects which impedes the reduction of bank performance. State banks tend to generate much larger credit risk, which induce lower performance (Farazi et al., 2013).

In most regressions, the bank size explains the variation of performance. Our finding indicates that the size of banks (Size) is significant and positive. It appears that large banks, due to the economies of scale, have the experience and the necessary resources to properly monitor managers and increase the performance. Our result confirms the finding of Kwan (2003) for Asian economies. The finding reveals that bank capital has a significant positive impact on performance. Indeed, the higher the equity to the total assets ration the lower the need to external funding and therefore, the higher the profitability of the bank (Golin, 2001). Our findings corroborate the results of Berger (1995) and Demirgüç-Kunt and Huizinga (2000) who find a positive relationship between bank performance and capitalization.

Furthermore, the charter value banks have a significant and negative impact on their performance. Banks with high charter value are associated with higher ROA and ROE. Besides, GDP growth exhibits positive and statistically significant relationship in all regression models. This result suggests that the economic growth ameliorate the financial sector performance in MENA region.

Also, NPLs is significant exhibiting negative relationship with ROE and ROA. The results indicate that less profitable banks are involved in riskier activities. We conclude that MENA banks with high risk perform worse. Indeed, according to financial theory, profitability is an increasing function of risk. Banks take more risk to increase their profitability. Finally, we notice that the coefficient on institutional quality variable $(I Q)$ is significant and positive in all regressions. Our findings highlight the importance of institutional environment in enhancing bank performance in MENA region. 
Table 3. Ownership concentration and bank performance

\begin{tabular}{|c|c|c|}
\hline \multirow{2}{*}{ Independent variables } & ROA & ROE \\
\hline & Model 1 Coeff. (t) & Model 2 Coeff. (t) \\
\hline \multirow{2}{*}{ Constant } & 0.368 & 0.149 \\
\hline & $(9.781)^{* * *}$ & $(1.671)^{*}$ \\
\hline \multirow{2}{*}{ ROA (-1) } & 0.623 & \\
\hline & $(50.22)^{* * *}$ & - \\
\hline \multirow{2}{*}{ ROE (-1) } & & 0.355 \\
\hline & - & $(48.037)^{* * *}$ \\
\hline \multirow{2}{*}{$\mathrm{OC} 1$} & 0.056 & 0.027 \\
\hline & $(9.416)^{* * *}$ & $(3.758)^{* * *}$ \\
\hline \multirow{2}{*}{$\mathrm{OC} 2$} & 0.053 & 0.020 \\
\hline & $(8.498)^{* * *}$ & $(2.149)^{* *}$ \\
\hline \multirow{2}{*}{$\mathrm{OC} 3$} & 0.021 & 0.019 \\
\hline & $(3.980)^{* * *}$ & $(2.474)^{* *}$ \\
\hline \multirow{2}{*}{ Size } & 0.016 & 0.003 \\
\hline & $(21.603)^{* * *}$ & $(1.413)$ \\
\hline \multirow{2}{*}{ Capital } & 0.436 & 0.980 \\
\hline & $(15.477)^{* * *}$ & $(7.421)^{* * *}$ \\
\hline \multirow[t]{2}{*}{ NPLs } & -0.171 & -0.366 \\
\hline & $(-18.268)^{* * *}$ & $(-11.137)^{* * *}$ \\
\hline \multirow{2}{*}{ Charter } & -0.235 & -0.110 \\
\hline & $(-8.952)^{* * *}$ & $(-2.433)^{* *}$ \\
\hline \multirow{2}{*}{ GDP_gr } & 0.213 & 0.155 \\
\hline & $(63.345)^{* * *}$ & $(2.257)^{* *}$ \\
\hline \multirow{2}{*}{ IQ } & 0.044 & 0.034 \\
\hline & $(36.847)^{* * *}$ & $(4.713)^{* * *}$ \\
\hline Year dummies & Yes & Yes \\
\hline Observations & 254 & 257 \\
\hline \multirow{2}{*}{ Sargan test } & 22.329 & 25.821 \\
\hline & $(0.67)$ & $(0.47)$ \\
\hline \multirow{2}{*}{$\mathrm{AR}(1)$} & -2.461 & -2.093 \\
\hline & $(0.01)^{* *}$ & $(0.03)^{* *}$ \\
\hline \multirow{2}{*}{$\operatorname{AR}(2)$} & -0.907 & -0.940 \\
\hline & $(0.36)$ & $(0.34)$ \\
\hline $\mathrm{N}^{\circ}$ of instruments & 37 & 43 \\
\hline
\end{tabular}

Note. ${ }^{*} \mathrm{p}<0.01 ; * * \mathrm{p}<0.05 ; * * * \mathrm{p}<0.001$.

All variables are defined in table 1. The dependent variables are the ROA in model (1) and the ROE in model (2). $A R(1)$ and $A R(2)$ are t-statistics for first and second order serial correlation. Sargan is a test of the over-identifying restrictions under the null that the instruments are valid. The right-hand side variables are treated as endogenous using lags back from $\mathrm{t}-2$ as instruments. 
Table 4. Ownership structure and bank performance

\begin{tabular}{|c|c|c|}
\hline \multirow{2}{*}{ Independent variables } & ROA & ROE \\
\hline & Model 3 Coeff. (t) & Model 4 Coeff. (t) \\
\hline \multirow{2}{*}{ Constant } & 0.931 & -0.029 \\
\hline & $(55.998)^{* * *}$ & $(-0.424)$ \\
\hline \multirow{2}{*}{ ROA (-1) } & 0.620 & - \\
\hline & $(56.276)^{* * *}$ & \\
\hline \multirow{2}{*}{ ROE (-1) } & & 0.366 \\
\hline & & $(40.188)^{* * *}$ \\
\hline \multirow{2}{*}{ State } & -0.007 & -0.041 \\
\hline & $(-0.896)$ & $(-3.419)^{* * *}$ \\
\hline \multirow{2}{*}{ Foreign } & 0.099 & 0.023 \\
\hline & $(37.675)^{* * *}$ & $(3.885)^{* * *}$ \\
\hline \multirow{2}{*}{ Size } & 0.031 & 0.008 \\
\hline & $(46.855)^{* * *}$ & $(3.472)^{* * *}$ \\
\hline \multirow{2}{*}{ Capital } & 0.110 & 0.934 \\
\hline & $(6.819)^{* * *}$ & $(8.265)^{* * *}$ \\
\hline \multirow{2}{*}{ NPLs } & -0.061 & -0.366 \\
\hline & $(-13.155)^{* * *}$ & $(-11.137)^{* * *}$ \\
\hline \multirow{2}{*}{ Charter } & -0.479 & -0.182 \\
\hline & $(-24.129)^{* * *}$ & $(-4.234)^{* *}$ \\
\hline \multirow{2}{*}{ GDP_gr } & 0.004 & 0.194 \\
\hline & $(3.463)^{* * *}$ & $(4.178)^{* * *}$ \\
\hline \multirow{2}{*}{ IQ } & 0.092 & 0.053 \\
\hline & $(83.426)^{* * *}$ & $(5.442)^{* * *}$ \\
\hline Year dummies & Yes & Yes \\
\hline Observations & 254 & 257 \\
\hline \multirow{2}{*}{ Sargan test } & 23.318 & 24.784 \\
\hline & $(0.61)$ & $(0.53)$ \\
\hline \multirow{2}{*}{$\mathrm{AR}(1)$} & -2.450 & -2.094 \\
\hline & $(0.01)^{* *}$ & $(0.03)^{* *}$ \\
\hline \multirow{2}{*}{$\operatorname{AR}(2)$} & -0.940 & -0.921 \\
\hline & $(0.34)$ & $(0.35)$ \\
\hline $\mathrm{N}^{\circ}$ of instruments & 36 & 42 \\
\hline
\end{tabular}

Note. ${ }^{*} \mathrm{p}<0.01 ; * \mathrm{p}<0.05 ; * * * \mathrm{p}<0.001$.

All variables are defined in table 1. The dependent variables are the ROA in model (3) and the ROE in model (4). $\mathrm{AR}(1)$ and $\mathrm{AR}(2)$ are t-statistics for first and second order serial correlation. Sargan is a test of the over-identifying restrictions under the null that the instruments are valid. The right-hand side variables are treated as endogenous using lags back from $\mathrm{t}-2$ as instruments.

\section{Conclusion}

This paper examines, empirically, the impact of the ownership structure on the performance of MENA banks over the 2004-2011 period. Our research highlights the fact that ownership concentration play a central role in the governance of MENA banks and these structures also determine the performance of these banks. Our results indicate that ownership concentration have a significant and positive impact on bank performance. The state ownership deteriorates the performance of MENA banks. However, we show that banks with a higher proportion of foreign shareholders perform better than other domestic banks.

There are a number of policy implications related to our study. Given the vital role and the importance of banking governance in the economy, we think that number of governance challenges remain for banks in MENA region. Our result confirms the supremacy of MENA private banks in a matter of performance, which is a clear signal to encourage the privatization of state owned banks. The MENA banking sector is still dominated by state banks and privatizing these institutions is recommended in order to ameliorate their performance. Besides, even in the cases where the presence of state banks may be sustained, governance structure of these banks must be reviewed and authorities should minimize political interference and avoid credit misallocation. Also, greater 
foreign participation in MENA banks must be encouraged.

Recently, most MENA countries have reduced the share of state bank and allowed the entry of foreign investors, particularly foreign banks. Therefore, further efforts must be taken to foster growth in the region. The authorities of MENA countries need to take effective measures to modernize their banking systems. These include implementation of prudential regulation and risk management frameworks and enhancing supervisory responsibilities. These measures can positively contribute to promote performance and control for excessive risk taking.

However, our study presents some limitations and deserves future research. First a possible extension would be to examine the impact of board of directors on MENA bank performance. Second, Many MENA banks are part of large and closely controlled business groups. It would be worthwhile to incorporate the related lending in a future study to better understand the interactions and relationships between large shareholders and managers and to determine the potential effects of these interactions on bank performance.

\section{Acknowledgements}

Dr. Boussaada and Dr. Karmani aknowledge the editor and the external reviewer of the International Journal of Business and Management for useful comments.

\section{References}

Al-Amarneh, A. (2014). Corporate governance, ownership structure and bank performance in Jordan. International Journal of Economics and Finance, 6(6), 192-202. http://dx.doi.org/10.5539/ijef.v6n6p192

Andres, P., \& Vallelado, E. (2008). Corporate governance in banking: The role of the board of directors. Journal of Banking and Finance, 32, 2570-2580. http://dx.doi.org/10.1016/j.jbankfin.2008.05.008

Arellano, M., \& Bover, O. (1995). Another look at the instrumental variable estimation of error-components models. Journal of Econometrics, 68, 29-35. http://dx.doi.org/10.1016/0304-4076(94)01642-D

Atkinson, A. B., \& Stiglitz, J. E. (1980). Lectures on Public Economics. New York: Mc-Graw Hill.

Ayadi, R., Arbak, E., Ben Naceur, S., \& Casu, B. (2011). Convergence of banking sector regulations and its impact of bank performance and growth: The case of Algeria, Egypt, Morocco and Tunisia. Femise Report $n^{\circ}$ FEM 33-04.

Azofra, V., \& Santamaria, M. (2011). Ownership, control, and pyramids in Spanish commercial banks. Journal of Banking and Financ, 35, 1464-1476. http://dx.doi.org/10.1016/j.jbankfin.2010.10.029

Banerjee, A. (1997). A theory of misgovernance. Quarterly Journal of Economics, 45, 885-913.

Barth, J. R., Caprio J. G., \& Levine, R. (2004). Bank regulation and supervision: What works best? Journal of Financial Intermediation, 13, 205-248. http://dx.doi.org/10.1016/j.jfi.2003.06.002

Basel Committee on Banking Supervision. (2014). Principles for Enhancing Corporate Governance. Retrieved from http://www.bis.org/publ/bcbs176.pdf

Beck, T., Cull, R., \& Jerome A. (2005). Bank privatization and performance: Empirical evidence from Nigeria. Journal of Banking and Finance, 29, 2355-2379. http://dx.doi.org/10.1016/j.jbankfin.2005.03.018

Bektas, E., \& Kaymak, T. (2009). Governance mechanisms and ownership in an emerging market: The case of Turkish banks. Emerging Markets Finance and Trade, 45, 20-32.

Bennaceur, S., \& Goaied, M. (2008). The Determinants of Commercial Bank Interest Margin and Profitability: Evidence from Tunisia. Frontiers in Finance and Economics, 5, 106-130.

Berger A. (1995). The relationship between capital and earnings in banking. Journal of Money, Credit and Banking, 27, 404-431.

Berger, A. N., Clarke, G. R. G., Cull, R., Klapper, L., \& Udell, G. F. (2005). Corporate governance and bank performance: A joint analysis of the static, selection and dynamic effects of domestic, foreign and state

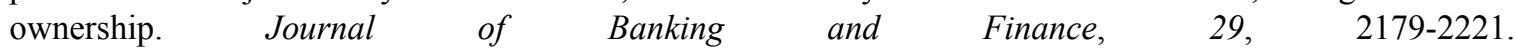
http://dx.doi.org/10.1016/j.jbankfin.2005.03.013

Berger, A. N., DeYoung, R., Genay, H., \& Udell, G. F. (2000). The globalization of financial institutions: Evidence from cross-border banking performance. Brookings-Wharton Papers on Financial Services, 3, 23-158.

Berle, A., \& Means, G. (1932). The modern corporation and private property. New York: Macmillan. 
Blundell, R., \& Bond, S. (1998). Initial Conditions And Moment Restrictions in Dynamic Panel Data Models. Journal of Econometrics, 87, 115-143. http://dx.doi.org/10.1016/S0304-4076(98)00009-8

Bonin, J., Hasan, I., \& Wachtel, P. (2005). Bank performance, efficiency and ownership in transition countries, Journal of Banking and Finance, 29, 31-53. http://dx.doi.org/10.1016/j.jbankfin.2004.06.015

Boyd, J. H., Chang, C., \& Smith, B. D. (1998). Moral hazard under commercial and universal banking. Journal of Money, Credit and Banking, 30, 426-468.

Breuer, J. B. (2006). Problem bank loans, conflicts of interest and institutions. Journal of Financial Stability, 2, 266-285. http://dx.doi.org/10.1016/j.jfs.2006.07.001

Caprio, G., Laeven, L., \& Levine, R. (2007). Governance and bank valuation. Journal of Financial Intermediation, 16, 584-617. http://dx.doi.org/10.1016/j.jfi.2006.10.003

Chatterjee, S., \& Price, B. (1991). Regression Analysis by example (2nd ed.). New York: Wile.

Choi, S., \& Hasan, I. (2005). Ownership, Governance, and Bank Performance: Korean Experience. Financial Markets, Institutions and Instruments, 14, 215-242. http://dx.doi.org/10.1111/j.0963-8008.2005.00104.x

Claessens, S., Demirgüc-Kunt, A., \& Huizinga, H. (2001). How does Foreign Entry Affect Domestic Banking Markets? Journal of Banking and Finance, 25, 891-991. http://dx.doi.org/10.1016/S0378-4266(00)00102-3

Creane, G., Goyal, R., Mobarak, M., \& Sab, R. (2004). Financial sector development in the Middle East and North Africa. IMF Working Paper WP/04/201.

De Young, R., \& Nolle, D. (1996). Foreign owned banks in the US: earning market share or buying it? Journal of Money, Credit and Banking, 28(4), 622-636.

Demirgüç-Kunt, A., \& Huizinga, H. (2000). Determinants of commercial bank interest margins and profitability: Some international evidence. World Bank Economic Review, 13(2), 379-408.

Demsetz, H., \& Villalonga, B. (2001). Ownership structure and corporate performance. Journal of Corporate Finance, 7, 209-233. http://dx.doi.org/10.1016/S0929-1199(01)00020-7

Douma, S., George, R., \& Kabir, M. (2006). Foreign and domestic ownership, business groups, and firm performance: Evidence from a large emerging market. Strategic Management Journal, 27(7), 637-657. http://dx.doi.org/10.1002/smj.535

Farazi, S., Feyen, E., \& Rocha, R. (2013). Bank Ownership and Performance in the Middle East and North Africa Region. Review of Middle East Economics and Finance, 9(2), 159-196. http://dx.doi.org/10.1515/rmeef-2012-0025

Golin, J. (2001). The Bank Credit Analysis Handbook: A Guide for Analysts, Bankers and Investors. John Wiley $\&$ Sons (Asia) Pre Ltd.

Gonzalez, F. (2005). Bank regulation and risk taking incentives: An international comparison of bank risk. Journal of Banking and Finance, 29, 1153-1184. http://dx.doi.org/10.1016/j.jbankfin.2004.05.029

Gulamhussen, M. A., \& Guerreiro, L. (2009). The influence of foreign equity and board membership on corporate strategy and internal cost management in Portuguese banks. Management Accounting Research, 20, 6-17. http://dx.doi.org/10.1016/j.mar.2008.10.006

Gutiérrez, M., \& Tribó, J. A. (2004). Private Benefits Extraction in Closely-held Corporations: The Case for Multiple Large Shareholders. Working Paper, European Corporate Governance Institute.

Hasan, I., \& Marton, K. (2003). Development and efficiency of the banking sector in a transitional economy: Hungarian experience. Journal of Banking \& Finance, 27, 2249-2271. http://dx.doi.org/10.1016/S0378-4266(02)00328-X

Haw, I., Simon, S. M. H., Hu, B., \& Donghui, W. (2010). Concentrated control, institutions and banking sector: An international study. Journal of Banking and Finance, 34, 485-497. http://dx.doi.org/10.1016/j.jbankfin.2009.08.013

Hu, J. L., Li, Y., \& Chiu, Y. H. (2004). Ownership and Non-performing Loans: Evidence from Taiwan's Banks. Developing Economies, 42(3), 405-420. http://dx.doi.org/10.1111/j.1746-1049.2004.tb00945.x

Iannotta, G., Nocera, G., \& Sironi, A. (2007). Ownership structure, risk and performance in the European banking industry. Journal of Banking and Finance, 31, 2127-2149. http://dx.doi.org/10.1016/j.jbankfin.2006.07.013 
Isik, I., \& Hassan, M. K. (2003). Financial Deregulation and Total Factor Productivity Change: An Empirical Study of Turkish Commercial Banks. Journal of Banking and Finance, 27(8), 1455-1485. http://dx.doi.org/10.1016/S0378-4266(02)00288-1

Isik, I., Gunduz, L., \& Omran, M. (2004). Managerial and Scale Efficiency in the MENA Banking: A Panel Study of the Jordanian Banking Sector. SSRN Working Paper.

Jensen, M., \& Meckling, W. (1976). Theory of the firm: Managerial behavior, agency costs and ownership structure. Journal of Financial Economics, 3, 305-360. http://dx.doi.org/10.1007/978-94-009-9257-3_8

Johnson, S., La Porta, R., Lopez de Silanes, F., \& Shleifer, A. (2000). Tunneling. American Economic Review, 90, 22-27.

Kaufmann, D., Kraay, A., \& Mastruzziet, M. (2010). The Worldwide Governance Indicators: Methodology and Analytical Issues. World Bank Policy Research Working Paper, $\mathrm{n}^{\circ} 5430$.

Keeley, M. C. (1990). Deposit insurance, risk and market power in banking. The American Economic Review, 80, $1183-1200$.

Kennedy, P. (2003). A guide to econometric (5th ed.). Cambridge: The MIT Press.

King R. G., \& Levine, R. (1993). Finance and growth: Schumpeter might be right. Quarterly Journal of Economics, 108, 717-737.

Kobeissi, N., \& Sun, X. (2010). Ownership structure and bank performance: Evidence from the Middle East and North Africa Region. Comparative Economic Studies, 52, 287-323. http://dx.doi.org/10.1057/ces.2010.10

Kwan, S. H. (2003). Operating performance of banks among Asian economies: An international and time series

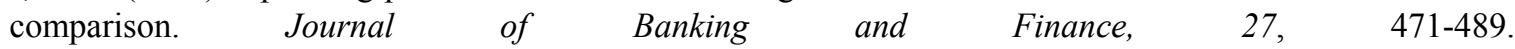
http://dx.doi.org/10.1016/S0378-4266(02)00384-9

La Porta, R., Lopez-de-Silanes, F., \& Shleifer, A. (2002). Government ownership of commercial banks. Journal of Finance, 57, 265-301. http://dx.doi.org/10.1111/1540-6261.00422

Laeven, L. A., \& Levine, R. (2009). Bank Governance, Regulation, and Risk. Journal of Financial Economics, 93, 259-275. http://dx.doi.org/10.1016/j.jfineco.2008.09.003

Lensink, R., \& Hermes, N. (2004). The short-term effects of foreign bank entry on domestic bank behaviour: Does economic development matter? Journal of Banking and Finance, 28(3), 553-568. http://dx.doi.org/10.1016/S0378-4266(02)00393-X.

Levine, R. (1997). Financial development and economic growth: Views and agenda. Journal of Economic Literature, 35(2), 688-726.

Levy, Y. E., Micco, A., \& Panizza, U. (2007). A Reappraisal of State-Owned Banks. Ecomonia, 7(2), 209-247.

Lin, X., \& Zhang, Y. (2009). Bank ownership reform and bank performance in China. Journal of Banking and Finance, 33, 20-29. http://dx.doi.org/10.1016/j.jbankfin.2006.11.022.

Maati, J., \& Maati-Sauvez, C. (2012). Corporate governance of banks and risk management by stockholders. Bankers, Markets \& Investors, 120, 50-66.

Mahajan, P., Bhatia, A., \& Subhasch, C. (2012). ROA performance of public sectors banks in India. The IUP Journal of Bank Management, 11, 22-35.

Megginson, W. (2005). The economics of bank privatization. Journal of Banking and Finance, 29, 1931-1980. http://dx.doi.org/10.1016/j.jbankfin.2005.03.005

Micco, A., Panizza, U., \& Yañez, M. (2004). Bank Ownership and Performance Inter-American Development Bank. Research Department Working Paper, 518.

Micco, A., Panizza, U., \& Yanez, M. (2007). Bank Ownership and Performance: Does Politics Matter. Journal of Banking and Finance, 31, 219-241. http://dx.doi.org/10.1016/j.jbankfin.2005.03.005

Mohieldin, M., \& Nasr, S. (2007). On bank privatization: The case of Egypt. The Quarterly Review of Economics and Finance, 46, 707-725. http://dx.doi.org/10.1016/j.qref.2006.08.011

Morgan, D. (2002). Rating banks: Risk and uncertainty in an opaque industry. American Economic Review, 92, 847-888.

Omran, M. (2007). Privatization, State Ownership, and Bank Performance in Egypt. World Development, 35, 714-733. http://dx.doi.org/10.1016/j.worlddev.2006.07.002 
Pathan, S. (2009). Strong boards, CEO power and bank risk-taking. Journal of Banking and Finance, 33, 1340-1350. http://dx.doi.org/10.1016/j.jbankfin.2009.02.001

Pathan, S., Skully, M., \& Wickramanayake, J. (2007). Board size, independences and performance: An analysis of Thai banks. Asia-Pacific Financial Markets, 14, 211-227. http://dx.doi.org/10.1007/s10690-007-9060-y

Rochat, R. R., Arvai, Z., \& Farazi, S. (2011). Financial Access and Stability: A Road Map for the Middle East and North Africa. The World Bank Report.

Salas, V., \& Saurina, J. (2003). Deregulation, market power and risk behaviour in Spanish banks. European Economic Review, 47, 1061-1075. http://dx.doi.org/10.1016/S0014-2921(02)00230-1

Sapienza, P. (2004). The Effects of Government Ownership on Bank Lending. Journal of Financial Economics, 72, 357-384. http://dx.doi.org/10.1016/j.jfineco.2002.10.002

Shehzad, C. T., De Haan, J., \& Scholtens, B. (2010). The impact of bank concentration on impaired loans and capital adequacy. Journal of Banking and Finance, 34, 399-408. http://dx.doi.org/10.1016/j.jbankfin.2009.08.007

Shleifer, A., \& Vishny, R. W. (1986). Large shareholders and corporate control. Journal of Political Economy, 94 , 461-489.

Shleifer, A., \& Vishny, R. W. (1994). Politicians and Firms. Quarterly Journal of Economics, 109, 995-1025.

Shleifer, A., \& Vishny, R. W. (1997). A survey of corporate governance. Journal of Finance, 52, 737-783. http://dx.doi.org/10.1111/j.1540-6261.1997.tb04820.x

Stulz, R. M. (1988). Managerial control of voting rights: financing policies and the market for corporate control. Journal of Financial Economics, 20, 25-54. http://dx.doi.org/10.1016/0304-405X(88)90039-6

Turk-Ariss, R. (2008). Financial Liberalization and Bank Efficiency: Evidence from Post-war Lebanon. Applied Financial Economics, 18, 931-946. http://dx.doi.org/10.1080/09603100701335408

Unite, A. A., \& Sullivan, M. J. (2003). The effect of foreign entry and ownership structure on the Philippine domestic banking market. Journal of Banking and Finance, 27, 2323-2345. http://dx.doi.org/10.1016/S0378-4266(02)00330-8

Vander, V. R. (1996). The effects of mergers and acquisitions on the efficiency and profitability of EC credit institutions. Journal of Banking and Finance, 2, 1531-1558. http://dx.doi.org/10.1016/S0378-4266(96)00014-3

Weill, L. (2007). Is there a gap in bank efficiency between CEE and Western European countries? Comparative Economic Studies, 49, 101-127. http://dx.doi.org/10.1057/palgrave.ces.8100183

Williams, J., \& Nguyen, N. (2005). Financial liberalization, crisis and restructuring: A comparative study of bank performance and bank governance in South East Asia. Journal of Banking and Finance, 29, 2119-2154. http://dx.doi.org/10.1016/j.jbankfin.2005.03.011

Windmeijer, F. (2005). A finite sample correction for the variance of linear efficient two-step GMM estimators. Journal of Econometrics, 126, 25-51. http://dx.doi.org/10.1016/j.jeconom.2004.02.005

\section{Notes}

Note 1. Latin America, China and Central and Eastern Europe.

Note 2. Tunisia, Morocco, Egypt, Lebanon, Jordan, Qatar, Oman, Bahrain, United Arab Emirates and Saudi Arabia.

Note 3. The banks remain solvent as a result of strong initial capital positions and forceful measures by country authorities.

Note 4. We use the World Governance Indicators 2012 update that incorporates revision to data for previous years.

Note 5. Chatterjee and Price (1991) explain that a strong multicollinearity is detected when the value of VIF is greater than 10.

Note 6. For all estimations, the Sargan test of over identifying restriction of the instruments has not rejected the null hypothesis of valid instruments. 


\section{Appendix A}

Table A. The correlation matrix of Pearson

\begin{tabular}{|c|c|c|c|c|c|c|c|c|c|c|c|c|c|}
\hline & $\mathrm{ROA}$ & ROE & $\mathrm{OC} 1$ & OC 2 & OC3 & State & Foreign & Size & NPLs & Capital & Charter & Gdp_gr & IQ \\
\hline ROA & 1 & & & & & & & & & & & & \\
\hline ROE & 0.06 & 1 & & & & & & & & & & & \\
\hline OC1 & $0.13 *$ & $-0.14^{*}$ & 1 & & & & & & & & & & \\
\hline OC 2 & $0.20 *$ & $-0.01 * *$ & $0.11 *$ & 1 & & & & & & & & & \\
\hline OC 3 & $-0.15^{*}$ & 0.03 & $-0.55^{*}$ & $-0.41^{*}$ & 1 & & & & & & & & \\
\hline State & -0.08 & -0.05 & -0.04 & $0.10^{* *}$ & $-0.12 *$ & 1 & & & & & & & \\
\hline Foreign & 0.02 & 0.09 & -0.00 & $-0.25 *$ & $0.30^{*}$ & $-0.39 *$ & 1 & & & & & & \\
\hline Size & $-0.19^{*}$ & $0.26^{*}$ & -0.01 & -0.08 & 0.06 & -0.00 & $0.32 *$ & 1 & & & & & \\
\hline NPLs & -0.02 & $-0.32 *$ & -0.03 & $-0.19^{*}$ & $0.23 *$ & 0.05 & -0.03 & $-0.39 *$ & 1 & & & & \\
\hline CAPITAL & $0.13^{*}$ & -0.04 & -0.02 & -0.02 & $-0.16^{*}$ & $-0.16^{*}$ & -0.02 & -0.16 & $-0.14 *$ & 1 & & & \\
\hline Charter & $-0.14 *$ & -0.05 & $0.15^{*}$ & $-0.23 *$ & $0.13 * *$ & 0.07 & $0.23 *$ & $-0.14^{*}$ & $0.16^{*}$ & $-0.49^{*}$ & 1 & & \\
\hline Gdp_gr & 0.03 & $0.10^{* *}$ & -0.02 & $0.11^{*}$ & -0.02 & $-0.13^{*}$ & $0.14 *$ & 0.09 & $-0.22 *$ & $0.33 *$ & $-0.34 *$ & 1 & \\
\hline IQ & $0.23^{*}$ & -0.02 & -0.00 & $0.25^{*}$ & $-0.23^{*}$ & $0.19 *$ & $-0.32 *$ & $-0.21^{*}$ & $-0.26^{*}$ & $0.45^{*}$ & $-0.32 *$ & $0.33 *$ & 1 \\
\hline
\end{tabular}

Note. $*$ Statically significant at $5 \%$ level; ** statically significant at $10 \%$ level.

\section{Copyrights}

Copyright for this article is retained by the author(s), with first publication rights granted to the journal.

This is an open-access article distributed under the terms and conditions of the Creative Commons Attribution license (http://creativecommons.org/licenses/by/3.0/). 